\title{
Pan African Feminist Perspectives Promoting Matriarchy. Women's Pre-Colonial Linguistic Power Perspectives, Power Loss and the Contemporary State of Affairs in Ankole Sub-Region
}

\author{
Donath Asiimire1, Medard Twinamatsiko² \\ ${ }^{1}$ Bishop Stuart University, Mbarara, Uganda \\ ${ }^{2}$ Mbarara University of science and Technology, Mbarara, Uganda \\ Email: dasiimire@beg.bsu.ac.ug, mtwinamatsiko@must.ac.ug
}

How to cite this paper: Asiimire, D. and Twinamatsiko, M. (2021) Pan African Feminist Perspectives Promoting Matriarchy. Women's Pre-Colonial Linguistic Power Perspectives, Power Loss and the Contemporary State of Affairs in Ankole SubRegion. Open Access Library Journal, 8: e7870.

https://doi.org/10.4236/oalib.1107870

Received: August 19, 2021

Accepted: November 12, 2021

Published: November 15, 2021

Copyright $\odot 2021$ by author(s) and Open Access Library Inc.

This work is licensed under the Creative Commons Attribution International License (CC BY 4.0).

http://creativecommons.org/licenses/by/4.0/

\begin{abstract}
This paper studies the linguistic approach used to describe wise, healer and powerful women in the Ankole Sub-region during the pre-colonial times. Discussed in the study are the names, words and proverbs that describe a general perspective of women and illustrate how women were powerful before colonialism. The paper also presents how women were later oppressed and lost power during the colonial period. Finally, the paper puts forwards ways of reclaiming women's power in the Ankole Sub-region.
\end{abstract}

\section{Subject Areas}

Sociology

\section{Keywords}

Women and Economic Power, Women and Political Power,

Women and Social Power

\section{Introduction}

This paper presents an intergenerational dialogue exploring aspects of Ankole matriarchal cultures through analysis of local languages. It builds on the theory of Magoqwana (2018) who argues that repositioning uMakhulu (grandmother in isiXhosa, a language spoken in Southern Africa) and Omukaikuru the Runyankore 
spoken in Ankole, Western Uganda. That results in the unearthing of an institution of indigenous knowledge and power that stores, transfers and disseminates knowledge and values. The paper analyses aspects of pre-colonial history and languages to illustrate the power and centrality of Ankole women in general and older women specifically. Words and proverbs from Runyankole about wise women, healer, power and leader were used.

Coupled with the use of languages, various historical contexts have been investigated to illustrate women's power and leadership. It is argued that the powerful positions of women as leaders, healers and institutional knowledge were eroded by colonization, religions, and indigenous patriarchy and is currently being promoted by "neo-traditionalism" camouflaged as African culture. What also informs the standpoint of this paper is the African Feminist Charter (2006) which asserts that: "I am inspired by our feminist ancestors' actions as leaders and wise women who facilitated our current strengths and continue their long tradition of resistance to patriarchy. I also claim the right to theorize for myself, write, strategize and assert my voice as an African feminist".

The structure of this paper is as follows: the paper presents the theory, women's political, economic and social power during pre-colonial, colonial and the current state of women's political, economic and social status in Ankole Sub-region.

\section{The Theory}

The study is premised on the Magoqwana theory (2018) which seeks to contest the constricted conceptions about the importance of a grandmother in an African family. The theory premises the roles of a grandmother beyond giving care under harsh conditions and focuses on a broader perspective. The theory places the grandmother in a position of someone well-grounded in history and as an oral story teller of the history that shapes children for spiritual awareness. The knowledge and skills obtained are a good grounding for determining leadership values.

The theory is also premised on the belief that a grandmother is good at ensuring public leadership with values, self-sufficiency, and respect through morality training. Finally, a grandmother is an expert at training for womanhood which a majority of Africans through patriarchy mistakenly call submissiveness and as such women are forced to see this as their traditional role.

The theory is relevant because Ankole needs to reconsider using the institution of grandmother Omukaikuru in sharing knowledge as the foundation for young children's curriculum and ways of teaching. This is vital in building towards a more accessible and complimentary history curriculum that sees the Ankole household as part of the learning spaces rather than divorced from knowledge. In positioning the Omukaikuru as the source of knowledge for primary school children it means acknowledging children's cultural base, language and innate intelligence, thus valuing their language and sense of being from an early age.

The theory is necessary because it proposes a new model of where knowledge 
is situated, how it should be communicated, the values carried in knowledge, and the bodies that carry this knowledge. In modelling the Omukaikuru as a form of institution of knowledge, one is able to deal with some of the challenges facing public institutions of knowledge today.

\section{Background}

Taking a closer look at Africa's history, the study done by Tripp (1994) [1] illustrates that women were more involved within the society. The study conducted by Barnes (1969) [2] and Tripp (2012) [3] confirms that women played social, political, economic and religious roles during pre-colonial times in Africa. Although such roles played by women have always been ignored by fronting men's works, Amadiume (2005) [4] says that matriarchy dominated African societies first and women were leading in almost all spheres of the society. This challenges the credence that only men were at the ancient front step in traditional African society and women were relegated to domestic chores only.

Presently, there are few researchers who "believe" that real and true matriarchy ever existed anywhere. For example, the study done by Farrar (1997) [5] provides that an anthropologist named Marvin Hanis dismisses matriarchy as a myth. To me matriarchy being a myth is a misconception because women were not failures. The work of Amadiume (1997) [6] reveals that matriarchy had begun in Africa before anywhere else in the word. This justifies that there existed a system of women's leadership in ancient and pre-colonial Africa. In fact, a close study of the works done by Diop (1989) [7] and Van Sertima (1994) [8] clarify that women during ancient and pre-colonial times in Africa were dominant in political, economic, social and religious activities and functions.

The current women's marginalized position in Ankole largely originated from the colonial rule that took over Africa between 1870s and 1900 (Tripp, 2012) [3]. The conquest and eventual colonisation of Africa led to a new system of administration that minimized women's position in Ankole. The new system of colonialists was a setback to Ankole women in political, economic, social and religious spheres. The work done by Tamale (2000) [9] proves that to date women are still struggling to gain their popular position within their societies. The major challenge hindering Ankole women's progress, is the struggle to gain their popular position under representation in influential positions like Tripp (2001) [10] extrapolates.

The main research question to be explored here is: how were Ankole women powerful before the colonial era, in political, economic and social/religious circles, how did the colonial rule affect women's power and how can this power be re-claimed?

\section{Pre-Colonial Period}

\subsection{Women and Political Power}

Despite the predominance of patriarchal societies throughout ancient times as 
noted by Afisi (2010) [11], women held very influential political positions during pre-colonial Ankole in Uganda. In fact, Busingye (2011) [12] shows that among other kingdoms in Uganda, Ankole kingdom had a majority of women in leadership as diviners and chiefs. These women included Murogo, Nyatuzana, Kishokye and Kibubwa. Important to note is that, the only female gombolola (subcounty) chief Julia Kibubura, appointed by the British administration, was from Ankole (Busingye, 2011 [12]; Tripp, 2012 [3]).

While it is factual that patriarchy did exist, Amadiume (2015) [13] and Tamale (2000) [9] confirm that women were not utterly detached from political positions. They played sensitive political roles on behalf of the King/Omugabe. For example, studies done by Mwakikagile (2009) [14] and Karamura (1998) [15] elaborate that the king of Ankole kingdom appointed Murongo as a spy among the Banyoro who were living in Ankole kingdom. Murongo together with her female descendants allegedly acted like cows and mingled with cattle keepers of the enemy. Murongo with her fellow descendants played this role for quite some time which gave them political popularity (Liebling, 2004 [16]; Tripp, 2012 [3]; Tumusiime, 2012 [17]).

Women during pre-colonial Ankole, were powerful in different aspects of the political realms and their power could be respected by community members (Tamale, 2000) [9]. Byanyima (1992) [18] states that women used informal means to influence decisions both at household and society levels. For example, in Ankole if people were unhappy or dissatisfied with aspects of the leadership of the Omugabe/ king, they would go through Omwigarire (king's wife) to intervene or mediate on their behalf. This intervention was called Okuhwera iba. The Omwigarire through care, attention and love for her husband, would present people's grievances and the Omugabe would accept his wife's advice. This was because community members always feared to present their political grievances directly to the Omugabe. Therefore, the Omwigarire/king's wife was the easiest means to influence political decisions (Kalervo Oberg, 1940 [19]; K Oberg, 1941 [19]; Williams, 1946 [20]).

While Weir (2006) [21] points out that women's leadership was inherent in South Africa during the pre-colonial era, Izabiliza (2003) [22] confirms that similar situations existed in Rwanda. They provide that, within the monarchy, the king executed his duties based on the decisions made by Umubagekazi (King's mother in Kinyarwanda language). In case the mother to the king died, her roles would be transferred to the daughter. Similarly, in Uganda and in Ankole in particular the mother to the king together with her daughters and sisters participated in political decision-making and their influence was never easily sidestepped by the Omugabe. The Omugabe believed and trusted in them for the right advice.

Elam (1975) [23] asserts that the Omugabe always consulted these women on many major political and social issues and their opinion carried great weight. The people within the kingdom knew that the mother to the Omugabe as well as 
the sister were powerful women and they were more respected than the King's brothers. The same respect was always extended to other women close to the King's mother and sister (Interview done by author with Kaparaga Mahuuku'). It is thus important that this area of powerful queen mothers in East Africa be further explored.

During the pre-colonial era women in Ankole were thought to have power to organize and lead societies very well. The study done by Katahweire (1989) [24] shows that it was within the political arrangement in Ankole kingdom that the King's mother should have a separate kingdom to rule over. Like Tripp (2012) [3] avers that in Buganda and Acholi, the king's mother had extraordinary powers. This was similar to Ankole because the queen mother dispensed political powers and justice over a village of her interest. She did not exercise this political power alone but rather with the other women she chose. For that matter she chose her own women close to her and especially in her lineage to assist in executing political powers. One can see that this gave women political prestige and direct influence in decision making (Tripp, 2012) [3].

Women were advisors and through their advice they influenced decisionmaking in sensitive political arenas during pre-colonial era in Ankole. A study done by Lebeuf (1963) [25] and Steinhart (1977) [26] expresses that it was upon women's guidance that men would be called good leaders. In Ankole kingdom, there was a council of wise women known as Abahangu (Interview done by author with Kaparaga Mahuuku). Kaparaga said that: "the king consulted the Abahangu for wisdom in cases of leadership or related issues. The Abahangu were women of great insight and sometimes they foretold the fate of his kingdom to the Omugabe. The Omugabe relied on the Abahangu for political, economic and social decisions. It was very common and ideal for the Omugabe to always make visits to the Abahangu in search of wisdom to enable him run the kingdom and to keep everything on track". Because of the Abahangu, it gave women influence and leverage in all societal spheres (Kalervo Oberg, 1940) [19].

Related to the above, the Abahangu always attended clan meetings and assemblies and their views were always respected, being wise women. They were always at the front line to present women's grievances and in case their issues were not given much attention, very little could be done. These women councils had very strong support from the community members and in most cases the final action to be taken by the clan members was a collective decision of the $\mathrm{Ba}$ haungu.

The political powers that women had in the pre-colonial Ankole were very instrumental resulting from the collective voice that women had unlike men. The council of wise women and women courts were established to preserve and uphold women's dignity. One can easily recognize that the political arrangement gave women an opportunity to exercise political power and authority. It would

${ }^{1}$ One of the clan elders of Bahinda clan where the king originated. He is well known for teaching the right Runyankole language so as to understand Ankole culture. 
thus be erroneous to argue that women in the pre-colonial Ankole were totally excluded from political leadership.

Interesting to consider is the study done by Karamura (1998, p. 48) [15] which elaborates that women at some point were a political pressure group, the first ever in Ankole's history. For example, on 16 December 1957, Catholic women wrote a memorandum to the Omugabe objecting to the Eishengyero's (The then parliament of Ankole Kingdom) decision to stop all people in Ankole kingdom from voting.

\subsection{Women and Economic Power}

Farming was the greatest significant economic occupation in pre-colonial Ankole (Steinhart \& Claessen, 1978) [27]. Millet, cassava, sweet potatoes, beans, ground nuts, and matooke constituted the main food crops grown by the people in Ankole communities. While women contributed much labour to farming, Carswell (2003) [28] and Good (1970) [29] clarify that all farm work associated with planting to harvesting were carried out by traditional women. N. Boric Leis (1964: 55) states that, "Agriculture is the utmost vital work done by women...... once the farming season commences, other works that a woman indulges in turn out to be of lesser value because she has to dedicate all her time to farming activities. Her economic cycle, trading and other chores are relegated to periods when farming work reduces or is completed."

Another area of debate is the innovative role played by women during the pre-colonial era in Ankole. A study conducted in Uganda by Tamale (2000) [9] avers that women were more involved in trading while men were in most cases interested in leisure. This means that women were creative, innovative and industrious. For example, Lebeuf (1963) [25] asserts that women were very good in pottery and the products were used for decoration, cooking, music instruments, collecting water, storage facilities and so on. This was referred to as the golden age for women during the pre-colonial times. Women in Ankole earned and controlled money got from art and craft which gave them more financial independence and they wielded mighty weapon over men. This is similar to what Rev Johnson Samuel (1969:125) wrote: "On the whole, the women seem to be far more industrious than the men, for whereas the men always contrive to have leisure hours and off days from work, the women seem to have none." If women in Ankole decided to abandon their economic roles then, the pre-colonial economy of Ankole would collapse (Lebeuf, 1963) [25].

In the pre-colonial Ankole, land was an important resource that belonged to the community and was controlled by women. The studies done by Afisi (2010) [11]; (Tripp, 2012) [3] confirm that women were predominantly responsible for Agricultural production. In Ankole kingdom, while the majority men were interested in political issues, women had the liberty to access, control and use land. However, the Omugabel king and his notable chiefs were located their own mailo land within the kingdom. The mailo land was also controlled and used by women. 
That is why Elam (1975) [23] says that women were squirrels, which meant that their families and communities depended on them for nourishment or else they would face starvation.

\subsection{Social and Religious Power}

This section considers the rights and duties of females in pre-colonial Ankole social and religious belief systems. Pre-colonial Ankole had numerous social and religious activities in which women played very significant functions. These roles include marriage ceremonies, funeral rites, religious as well as traditional festivals. In each of these activities, the women's age-grades were seriously involved. It goes on to give details concerning how women were central in religious and ritual functions and as such I show how they acted as curators of sacred objects, administered ritual medicines, acted as rain makers, presided over first harvests and controlled mourning ceremonies.

Women were in charge of all fruits and bush medicines which are cherished in the Kinyankore culture like (Kamatenesi-Mugisha \& Oryem-Origa, 2005) [30] provide. According to Kamatenesi-Mugisha and Oryem-Origa (2007) [31] and (Kamatenesi-Mugisha, Oryem-Origa, Odyek, \& Makawiti, 2008) [32] women used herbs to induce labour, cure or prevent diseases among children and adults, provided herbs for spicing up food and preventing bad luck.

Similarly, in some instances women presided over traditional functions like planting ceremonies because the community believed that if farmers were to get high yields some special women should preside over planting ceremonies. In some instances where farmers received little or no rainfall, they would invite women to come and dance and ask for rain from the gods. It was common that rainfall would follow after their departure. Women's power was imperative in all sectors of life and so no one could go without recognizing it (Kabera \& Ntozi, 1988) [33].

Culturally, there were names given to women who were well known for producing high yields. Such women were called Nyanjura (meaning rainfall givers) because every time they grew crops or presided over planting of crops, there was enough rainfall which increased yields. In a story book entitled "The Hidden Princess" Nyamwire (a clan name given to Basingo girls) tells a story of how her mother Nyanjura was always visited and requested by other women to be part of their planting team during the planting season. In fact Carswell (2003) [28] and Mushanga (1970) [34] elaborate that this gave such women social and religious prestige as controllers of land and food crop producers.

Under the traditional marriage custom in the Kinyankore culture, women determined child bearing. The study conducted by J. P. Ntozi and J. Kabera (1988) [35] indicates that it was upon a woman to determine the number of children to produce and also how such children should be cared for. There were no restrictions that hindered women from determining what is good for their children (Eilam, 1973) [36]. Therefore, women were in full control of their children's behaviour and future success. Women's stewardship role over children eventually 
determined how the societies were socially set up in the pre-colonial Ankole (Kingdoms, 2015 [37]; Roscoe, 1923 [38]).

In the pre-colonial society, women were entirely responsible for worship (Afisi, 2010) [11]. The pre-colonial religion was basically concerned with idol worship or the worship of small gods. Religious worship was presided over by women; they organized and determined procedures to follow as far as religious functions were concerned. It was alleged that women have expert skills in providing spiritual solutions to those who had different problems. It was through women therefore that the frustrated and the miserable found solutions for their problems. The dominance of women in religious ritual life gave them religious power to determine and influence societal worshiping procedures (Atekyereza, 2001 [39]; J. P. Ntozi \& J. B. Kabera, 1988 [35]; Vorhölter, 2012 [40]).

Similarly, women were responsible for conducting purification ceremonies and spirit initiation (SPIRIT, 2004) [41]. This was common in cases where someone was released from prison, coming from war or in menstruation for the case of women. In other words, women were relied upon to have knowledge concerning the appropriate rituals to perform on such people with problems.

If a religious leader foresaw evil, or if a diviner discovered that a citizen has offended the deities, the village head dispatched a town crier to consult with the women's leader as to how to embark on a ritual cleansing ceremony (Mushengyezi, 2003) [42].

Women also were responsible for Okuteera oruhoko (the practice of helping boys to marry in case girls had rejected them). This was through throwing a cock at the girl's home and smearing millet on the face of a girl. The two practices described the process whereby a boy whom the girls had deliberately refused to love or whom a particular girl had rejected could force the girl to marry him abruptly without her consent and much preparation. The vestiges of this practice still appear. Although the society decried this practice, it was public and helpful because the wrongdoer had to be charged an immense bride wealth.

\section{Colonial Context}

When colonialists took over Uganda on the $18^{\text {th }}$ June 1894 , the story of women in Ankole changed. The colonialists had a different political, social, religious and economic ideology contrary to the original order of Ankole kingdom. The study done by Tripp (2012) [3] confirms that the colonial ideologists were against women's progress because they regarded Ankole kingdom practices and setups as primitive. They advocated for new political, economic, social and religious styles of doing things. The new styles pushed women aside and they were strictly supposed to be involved in domestic activities only. Land became commercial, men went out of their homes to earn wages from cash crops and leadership was awarded on the decision of the colonial masters. This section, therefore, gives details of how women's influence in political, economic, social and religious spheres was negated and ignored. 


\subsection{Economic Deprivation}

In the first place, women lost admittance and control over the land and this made them more vulnerable because they had to depend on men for everything (Thai \& Turkina, 2013 [43]; Tripp, 2004b [44]). There were no more opportunities for women to control food production and its process. This is because land was now taken over by colonialists to grow cash crops and since women earned income from surplus food crops, this was no more. The situation put women at a great economic loss (Amadiume, 2015 [13]; Mamdani, 2018 [45]; Njoh, 2016 [46]). That is why the majority women are suffering up to today.

A majority of women who were much involved in trading of their handcrafts, crops, fruits and animal products could no longer access market places (Kayamba \& Kwesiga, 2016 [47]; Mushanga, 1970 [34]). According to the colonial guidelines, women and children were not supposed to go to urban centres but rather keep in villages and specifically in homes. One can clearly see that the already formed women's market networks could no longer hold. Women lost the platform to determine market prices of their commodities and this antagonized the future economic dreams of Ankole women like their counterparts in IyedeNigeria (Ogbomo, 2005) [48].

\subsection{Political Domination}

The study done by Mamdani (2014) [49] provides that since the colonialists' argument was that women should engage more in domestic work and remain in private domains, one can see that this was to bar women from getting involved in politics and do away with their political influence. The position of the king's wife, Omwigarire, mother and sister were all diminished and the colonial officials made different arrangements and provisions that did not cater for them in the new administrative design (Steinhart, 1977 [26]; Tamale, 2000 [9]). Women's political influence was ignored and it did not gain respect any more. The new administrative design established marked the end of women's active role and participation in political arenas (Chabal, 2016 [50]; Chrisman \& Williams, 2015 [51]; Mamdani, 2018 [45]; Rodney, 1972 [52]; Summers, 1991 [53]).

When Europeans colonised Africa, they primarily advocated for male-dominated politics, particularly in Ankole, and they ignored Ankole's long-established women's political activities and influence. By doing this, it denied women maturity and it made to be considered as property or awards to men (Staudt 1989) [54]. The kind of treatment offered to women wind-swept their autonomy and power, making them subordinates to men. The current women's struggles have been attributed to the male-dominated politics initiated by colonialists.

To actively participate in politics, one needs education in say political science, law, civics or English but only men were given such education. Women were given education that equipped them with skills to become better mothers, wives and home-makers. In other words, domestic skills in nutrition and home economics but not skills to participate in politics. Men's education was given a 
higher priority than that of women and women lost their political influence because they could not compete with men (Joireman, 2008 [55]; Tamale, 2000 [9]). While equipping women with skills to become good home-makers focusing on home economics and nutrition, their leadership attitude was diverted from leading societies to being good spouses and good mothers with emphasis dictated by the colonial masters.

Colonial rule emphasized high side-lining of women in political positions and as such their political position and influence was eroded within the society (Tamale, 2000) [9]. Subsequently, the majority men started to conceptualize that, women were unable to be leaders of societies and nations. This misconception is still being held by a majority of men in Ankole and Africa at large, as Fester (2004) [56] narrates. This is still reflected in small female numbers in parliamentary and ministerial positions in most ex-colonial countries (Bratton, 1989 [57]; Chrisman \& Williams, 2015 [51]; Mamdani, 2018 [45]; President \& Mbeki, 2004 [58]; Tripp, 2004b [44]).

\subsection{Social and Religious Loss of Status}

Women's religious and social roles in pre-colonial Ankole society was a byproduct of the status they occupied in that society. Women had numerous social and religious activities in which they played very significant functions. Basically, the polar social position women held consisted of rights and duties that could not be performed by any other individual within the society. The culture of Ankole people was diluted by colonialism, traditions were rendered less important and their ways of life were destroyed yet that is where women's power concentrated. Women could no longer preside over the traditional religious functions due to the introduction of Christianity.

The act of performing rituals by women in Ankole kingdom was no longer an important traditional practice that determined women's status. Previously, women scored highly in terms of satisfying societal needs and during the time of happiness or trouble. However, with the new society settings advanced by the colonial masters, these acts were disregarded as old fashioned. Women lost the opportunity to preside over first harvest, purification and religious ceremonies. The colonial masters rendered all those acts as backward, ungodly and satanic through the introduction of new styles of worship that were presided over by men appointed by colonial masters. This meant that women's religious respect got eroded.

The effect of the foreign government was reinforced by the missionaries and mission schools. Christian missions were established which at first had few converts but their influence by the 1930's was considered significant, generally among the young. A majority of people they had to profess Christianity in order to attend mission schools, and education was highly valued. But regardless of how nominal their membership was, they had to obey the rules so as to remain in good standing, and one rule was to avoid "pagan" rituals. Women were discouraged from attending such schools and worshiping was strictly supervised by co- 
lonial masters.

\section{Current Situation}

\subsection{Economic}

Uganda was the first African country to sign a gender equality agreement with the Private Sector Foundation (PSFU). PSFU aims to strengthen private sector capacity for effective policy advocacy and market competitiveness regionally, nationally and internationally. The adoption of Gender Equality seal by the Private Sector Foundation in Uganda (PSFU) is to close the gender gap through its implementation (Guloba, Ssewanyana, \& Birabwa, 2017 [59]; Stevenson \& St-Onge, 2005 [60]). However, implementation has never taken place due to the usual ambiguities in implementing gender policies.

Uganda Women Entrepreneurs Association (UWEA), has been challenged by the patriarchy tendencies in its attempt to enforce amplified involvement of professional business women in public procurement as evidenced by Komunte and Baguma (2016) [61]. Adopting a vendor charting study by the United Nations Development Program (UNDP) nation's office, to produce data on the worthiness and fraction of awards to women-owned enterprises and specialities is a very good strategy. Such data is imperative to validate and be utilized by Uganda Women Entrepreneurs Association (UWEA), to arrange a educational events that can equip parliamentarians and the legislative body with facts concerning gender mainstreaming in community procurement and entrepreneurship like Guloba et al. (2017) [59] provides.

The study done by Tripp, (2004b) [44] avers that the need to adopt the land policy is very urgent to cater for co-spousal consent and an easy land titling process affordable to women. The land policy proposing co-ownership by spouses in Uganda was adopted in 1998 but even to date it is still a bill and not yet a law. The argument has been and still is that it belongs to the domestic relations bill which is also not yet a law. Such bureaucratic tendencies have continuously affected women over land access and control. There is need to speed up the process so that women gain a platform for acquiring and controlling land (Allen, 2000 [62]; Asiimwe, 2001 [63]; Goode, 1989 [64]; Ntozi \& Kabera, 1991 [65]; Tripp, 2004b [44]; Turinawe et al., 2016 [66]).

Similarly, women being major producers of crops as provided by Tripp (2004b) [44], the need to be given mandate and freedom to own land through quick land policy arrangements is critical to everyone. This provision will enhance and motivate women towards creative ideas that can be implemented on land and increase food production for societal benefits. More so, women's access to land enables them to practice extensive agriculture, have food for consumption and more for sale. Through selling surplus food stuffs, women are in position to earn income to cater for their own needs as well as the needs of their families (Kayamba \& Kwesiga, 2016) [47]. Besides, the majority of women work in agricultural subsistence work, particularly crop production. Altogether, 60 percent of 
women list "cropping" as their occupation, as opposed to only 49 percent of men (Lawson, 2003) [67]. Women are more active in agriculture than men, particularly in food crop production, marketing, and processing of agricultural products. This is confirmed by the National Agricultural Advisory Services (NAADS) report (Mutema, 2019) [68].

Women represent nearly 40 percent of business owners with registered premises in the Uganda Business Register, but these businesses are more probable than those owned by men to be informal microenterprises with a small number of employees (Nkundabanyanga, Nakyeyune, \& Muhwezi, 2019) [69]. It is imperative to note that there are unclear laws that protect these women and even their business capacities are not recognised as a requirement to acquire loans for further business growth and development (Monteith \& Camfield, 2019) [70].

In addition to women's prominence in farming, women carry a brunt of reproductive tasks (Oriangi et al., 2019) [71]. This unpaid double workday contributes markedly to women's overburdening and poverty levels. This shows an imbalance in gender separation of work which is a chief contributor to poverty that should be dealt with. Women work substantially more than men in both the market and the household economies. On average their workday may be 50 percent longer, and their work is closely integrated with household production systems. The need to recognise and develop mechanisms for rewarding women's efforts in monetary terms is very urgent or else Uganda's poverty levels will remain high (Epule \& New, 2019) [72].

\subsection{Political Side-Lining}

In order for women to reclaim and gain political power in Ankole, Uganda as a country must implement the inaugurated institutional mechanisms for mainstreaming gender in policy design and implementation, public financing, statistical production, and performance measurement systems (Brown, 1996 [73]; Tuwor \& Sossou, 2008 [74]; Unterhalter, 2012 [75]). There is need for the Uganda government to practice the adopted political gender policy to ensure gender political equality. The policy deals with patriarchy which is a major barrier to women's active involvement and participation in political spheres (Mutibwa, 1992 [76]; Pankhurst, 2002 [77]; Tripp, 2001 [10], 2012 [3]).

The patterns of intimidation, harassment, and resistance to women's assertion of their political rights and freedoms are bound to persist. However, women need to be persistent in their opposition to patriarchal systems, but also to change their tools in their fight for change.

\subsection{Social and Religious Participation}

Women in Ankole have persistently failed to fully participate in and benefit from Development Programmes in Uganda due to formal and informal institutions, such as patriarchy, religion, family, marriage as well as social and cultural practices. Today there are cultural norms that still define communal values of 
suitable and unsuitable behaviour which hamper the attainment of gender equality.

Traditionally, reproductive roles are still highly gendered within Ankole subregion. For example, wives in the study done by Karimli, Samman, Rost, \& Kidder, (2016) [78] are still expected perform all reproductive roles and also do paid work outside their home. Meanwhile, men are least predictable to take nearly as much duty for their families as women, yet Godfrey (2010) [79] points that they are considered the chief economic breadwinners and household heads. In other words, women are over-worked and under-appreciated. It is imperative to recognise women's efforts in monetary terms so that they are able to improve their wellbeing and situations around them. In this regard, UNDP with MGLSD should work hand in hand to deal with ineffective laws which pose a big challenge to women unpaid work.

Today there has been increased sexual objectification through beauty queen contests, miss curvy contest and so on (Wright, 2017) [80]. Beauty standards make young girls and women think they must conform to characteristics of whiteness, thinness, and attractiveness. Women are constantly told that they have to be thin but also have curves with a big bust. Women have to stop hating their bodies, because if they do, it will be a revolutionary act in itself (Valenti, 2007). Women should be taught to value their intelligence, abilities, etc., instead of just valuing themselves for looking hot in a bikini and making themselves available to men.

In the study done by Tamale (2018) [81] women are still marginalized in Ugandan societies. In most cases if not all the time, women are believed not to act as go-between or be chairpersons of functions like weddings, giveaways or even burial ceremonies (Sentumbwe, 1995) [82]. These titles are always preserved for men and women deputize. Women need to be encouraged and supported by their fellow women to take up such positions. It is paradoxical to note that in some cases, some women feel comfortable with the given positions and this has persistently created gender gaps within Ankole's communities' social interactions.

The traditional practice and belief of Ankole does not accept women as heirs of their parents' property like Kagugube (2017) [83] infers. In situations where a woman is even more outstanding than her brothers, the parents will symbolically put a son as the heir to follow the tradition (Cooper, 2011) [84]. Our societies need to shift from the traditional ways of doing things. That is why (Rutakumwa et al., 2017) [85] says that women have also acquired education and they have the capacity to be heirs of their parents' property. Besides, women are always considered as less corrupt, therefore remaining in the shoes of her parents sustains family property and cooperation among children (Rutakumwa et al., 2017) [85].

There are still gender gaps in religious sects that discriminate women from men. The study by (Amone, 2018 [86]; Schulz, 2018 [87]) for example, scruti- 
nises that among the Muslims, women are not expected to sit with men during prayers. More so among the Anglicans and Catholics, Lubaale (2019) also observes that women are not given opportunity to be archbishops or bishops. It is only recently that women have been allowed to be priests or canons. It is high time religious leaders and organizations actively betroth in the execution of the 2030 Agenda for Sustainable Development in their communities, their own organizations, and in cooperation with each other. Lubaale (2019) [88] advises that religious scholars should continue to engage in dialogue amongst themselves and with the scientific community, to continue to support the progressive evolution of religious thinking and scientific discovery. Furthermore, by building guidance for sustainable development that addresses the moral, ethical, spiritual, and practical responses needed to transform the paradigm for a collective purpose.

\section{Conclusions}

By and large, a mere look at women's position today may lead one to believe that they were a minor group of people within Ankole Kingdom. However, women had very strong influence within Ankole society. Their power can only be understood if one took a close study and analysis of the special roles that women played within their families and societies at large. Women's power was both direct and indirect and it was because of their political, social and economic powers that families and societies existed sustainably.

However, when colonialists came, women lost out because colonialists came with different ideologies. The colonialists marginalized women's involvement in political, social and economic realms. They also undermined whatever roles women played and eventually colonial ideologies led to gender gaps. Collective action is vital through embracing the above suggested measures for women to regain power and create a fair and a just society for Ankole Sub-region.

\section{Conflicts of Interest}

The authors declare no conflicts of interest.

\section{References}

[1] Tripp, A.M. (1994) Gender, Political Participation and the Transformation of Associational Life in Uganda and Tanzania. African Studies Review, 37, 107-131. https://doi.org/10.2307/525115

[2] Barnes, L. (1969) African Renaissance. Gollancz, London.

[3] Tripp, A.M. (2012) Women and Politics in Uganda. University of Wisconsin Press, Madison.

[4] Amadiume, I. (2005) Theorizing Matriarchy in Africa: Kinship Ideologies and Systems. In: Oyěwùmí, O., Ed., Africa and Europe African Gender Studies A Reader, Palgrave Macmillan, New York, 83-98. https://doi.org/10.1007/978-1-137-09009-6 5

[5] Farrar, T. (1997) The Queenmother, Matriarchy, and the Question of Female Po- 
litical Authority in Precolonial West African Monarchy. Journal of Black Studies, 27, 579-597. https://doi.org/10.1177/002193479702700501

[6] Amadiume, I. (1997) Re-Inventing Africa: Matriarchy, Religion and Culture. Zed Books, London.

[7] Diop, C.A. (1989) The African Origin of Civilization: Myth or Reality. Chicago Review Press, Los Angeles.

[8] Van Sertima, I. (1994) African Origin of Ancient Egyptian Civilization. Journal of African Civilizations, 12, 1-18.

[9] Tamale, S. (2000) 'Point of Order, Mr Speaker': African Women Claiming Their Space in Parliament. Gender \& Development, 8, 8-15. https://doi.org/10.1080/741923783

[10] Tripp, A.M. (2001) The Politics of Autonomy and Cooptation in Africa: The Case of the Ugandan Women's Movement. The Journal of Modern African Studies, 39, 101128. https://doi.org/10.1017/S0022278X01003548

[11] Afisi, O.T. (2010) Power and Womanhood in Africa: An Introductory Evaluation. The Journal of Pan African Studies, 3, 229-238.

[12] Busingye, G. (2011) Politicization of Land Law and Gender Relations in Uganda: A Case Study. East African Journal of Peace and Human Rights, 227-249.

[13] Amadiume, I. (2015) Male Daughters, Female Husbands: Gender and Sex in an African Society. Zed Books Ltd., London. https://doi.org/10.5040/9781350221253

[14] Mwakikagile, G. (2009) Uganda: The Land and Its People. New Africa Press, Cape Town.

[15] Karamura, G.P. (1998) The Interplay of Christianity, Ethnicity and Politics in Ankole, Uganda, 1953-1993. University of Leeds, Leeds.

[16] Liebling, H.J. (2004) A Gendered Analysis of the Experiences of Ugandan Women War Survivors. University of Warwick, Coventry.

[17] Tumusiime, A.E. (2012) Art and Gender: Imag[in]ing the New Woman in Contemporary Ugandan Art, Book 1. University of South Africa.

[18] Byanyima, W.K. (1992) Women in Political Struggle in Uganda. In: Bystylzienski, J.M., Ed., Women Transforming Politics. Worldwide Strategy for Empowerment, Indiana University Press, Bloomington, 129-142.

[19] Oberg, K. (1940) The Kingdom of Ankole in Uganda. In: Fortes, M. and EvansPritchard, E.E., Eds., African Political Systems, Oxford University Press, London, 121-126.

[20] Williams, F.L. (1946) Nuwa Mbaguta, Nganzi of Ankole. Uganda Journal, 10, 124135.

[21] Weir, J. (2006) Chiefly Women and Women's Leadership in Pre-Colonial Southern Africa. HSRC Press, Cape Town.

[22] Izabiliza, J. (2003) The Role of Women in Reconstruction: Experience of Rwanda. Consultation on Empowering Women in the Great Lakes Region: Violence, Peace and Women's Leadership, Addis Ababa, 30 May-1 June 2003.

[23] Elam, Y. (1975) Family and Polity in Ankole: The Hima Household and the Absence of Age-Sets. Ethnology, 14, 163-171. https://doi.org/10.2307/3773087

[24] Katahweire, E. (1989) The Position of Women in Kinyankore Culture, with Particular Reference to the Church of Uganda in Ankole. The African Mind, 1, 199-226.

[25] Lebeuf, A.M. (1963) The Role of Women in the Political Organization of African Societies. In: Paulme, D., Ed., Women of Tropical Africa, Routledge, London, 93-119. 
[26] Steinhart, E.I. (1977) The Politics of Intrigue in Ankole: 1905. African Studies Review, 20, 1-16. https://doi.org/10.2307/523649

[27] Steinhart, E.I. and Claessen, H.J. (1978) Ankole: Pastoral Hegemony. In: Claessen, H.J.M. and Skalnik, P., Eds., The Early State, De Gruyter Mouton, Berlin, Boston, 131-151. https://doi.org/10.1515/9783110813326.131

[28] Carswell, G. (2003) Food Crops as Cash Crops: The Case of Colonial Kigezi, Uganda. Journal of Agrarian Change, 3, 521-551. https://doi.org/10.1111/1471-0366.00065

[29] Good, C.M. (1970) Rural Markets and Trade in East Africa: A Study of the Functions and Development of Exchange Institutions in Ankole, Uganda. Research Paper No. 128, University of Chicago, Chicago.

[30] Kamatenesi-Mugisha, M. and Oryem-Origa, H. (2005) Traditional Herbal Remedies Used in the Management of Sexual Impotence and Erectile Dysfunction in Western Uganda. African Health Sciences, 5, 40-49.

[31] Kamatenesi-Mugisha, M. and Oryem-Origa, H. (2007) Medicinal Plants Used to Induce Labour during Childbirth in Western Uganda. Journal of Ethnopharmacology, 109, 1-9. https://doi.org/10.1016/j.jep.2006.06.011

[32] Kamatenesi-Mugisha, M., Oryem-Origa, H., Odyek, O. and Makawiti, D.W. (2008) Medicinal Plants Used in the Treatment of Fungal and Bacterial Infections in and around Queen Elizabeth Biosphere Reserve, Western Uganda. African Journal of Ecology, 46, 90-97. https://doi.org/10.1111/j.1365-2028.2008.00935.x

[33] Kabera, J.B. and Ntozi, J. (1988) The Role of Marital Sexual Customs in Maintaining High Fertility in East Africa: The Case of Ankole in South-Western Uganda. In: $A f$ rican Population Conference, Vol. 1, International Union for the Scientific Study of Population, Liège, 55-61.

[34] Mushanga, M.T. (1970) Polygyny in Kigezi. Uganda Journal, 34, 201-210.

[35] Ntozi, J.P. and Kabera, J. (1988) Marriage Patterns in Ankole, South-Western Uganda. Eastern Africa Social Science Research Review, 4, 33-56.

[36] Eilam, I. (1973) The Social and Sexual Roles of Hima Women: A Study of Nomadic Cattle Breeders in Nyabushozi County, Ankole, Uganda. Manchester University Press, Manchester.

[37] Kingdoms, V. (2005) Ankole Kingdom. In: Middleton, J., Ed., World Monarchies and Dynasties, Routledge, London, 45.

[38] Roscoe, J. (1923) The Banyankole: T. Vol. 2, Cambridge University Press, Cambridge.

[39] Atekyereza, P.R. (2001) Socio-Cultural Change in Uganda: Emerging Perceptions on Bride Wealth. Journal of Cultural Studies, 3, 360-384.

[40] Vorhölter, J. (2012) Negotiating Social Change: Ugandan Discourses on Westernisation and Neo-Colonialism as Forms of Social Critique. The Journal of Modern African Studies, 50, 283-307. https://doi.org/10.1017/S0022278X12000055

[41] Spirit, A.C. (2004) Spirit Initiation in Ankole. In: Beattie, J. and Middleton, J., Eds., Spirit Mediumship and Society in Africa, Routledge, London, 290.

[42] Mushengyezi, A. (2003) Rethinking Indigenous Media: Rituals, 'Talking' Drums and Orality as Forms of Public Communication in Uganda. Journal of African Cultural Studies, 16, 107-117. https://doi.org/10.1080/1369681032000169302

[43] Thai, M.T.T. and Turkina, E. (2013) Entrepreneurship in the Informal Economy: Models, Approaches and Prospects for Economic Development. Routledge, London.

[44] Tripp, A.M. (2004) Women's Movements, Customary Law, and Land Rights in Af- 
rica: The Case of Uganda. African Studies Quarterly, 7, 1-19.

[45] Mamdani, M. (2018) Citizen and Subject: Contemporary Africa and the Legacy of Late Colonialism. Princeton University Press, Princeton. https://doi.org/10.23943/9781400889716

[46] Njoh, A.J. (2016) Tradition, Culture and Development in Africa: Historical Lessons for Modern Development Planning. Routledge, London. https://doi.org/10.4324/9781315235868

[47] Kayamba, W.K. and Kwesiga, P. (2016) The Role of Pottery Production in Development: A Case Study of the Ankole Region in Western Uganda. Net Journal of Social Sciences, 4, 81-90.

[48] Ogbomo, O.W. (2005) Women, Power and Society in Pre-Colonial Africa. Lagos Historical Review, 5, 49-74. https://doi.org/10.4314/lhr.v5i1.32524

[49] Mamdani, M. (2014) When Victims Become Killers: Colonialism, Nativism, and the Genocide in Rwanda. Princeton University Press, Princeton.

[50] Chabal, P. (2016) Power in Africa: An Essay in Political Interpretation. Palgrave Macmillan, London.

[51] Chrisman, L. and Williams, P. (2015) Colonial Discourse and Post-Colonial Theory: A Reader. Routledge, London. https://doi.org/10.4324/9781315656496

[52] Rodney, W. (1972) How Europe Underdeveloped Africa. Vol. 239, Bogle-L’Ouverture Publications, London.

[53] Summers, C. (1991) Intimate Colonialism: The Imperial Production of Reproduction in Uganda, 1907-1925. Signs, 16, 787-807. https://doi.org/10.1086/494703

[54] Staudt, K.A. (1981) Bureaucratic Resistance to Women's Programs: The Case of Women in Development. Paper Presented at the 76th Annual Meeting of the American Sociological Association, Toronto, 24-28 August 1981, 1-30.

[55] Joireman, S.F. (2008) The Mystery of Capital Formation in Sub-Saharan Africa: Women, Property Rights and Customary Law. World Development, 36, 1233-1246. https://doi.org/10.1016/j.worlddev.2007.06.017

[56] Fester, G. (2004) Challenges to Promote Gender Equality: Some Lessons from South Africa. Commission on Gender Equality, ProQuest LLC.

[57] Bratton, M. (1989) The Politics of Government-NGO Relations in Africa. World Development, 17, 569-587. https://doi.org/10.1016/0305-750X(89)90263-5

[58] President, S.A. and Mbeki, T. (2004) State of the Nation Address of the President of South Africa, Thabo Mbeki: Houses of Parliament, Cape Town.

[59] Guloba, M., Ssewanyana, S. and Birabwa, E. (2017) Fostering Rural Women Nonfarm Household Enterprises Financing through Local Groups. Economic Policy Research Centre.

[60] Stevenson, L. and St-Onge, A. (2005) Support for Growth-Oriented Women Entrepreneurs in Uganda. International Labour Organization, Geneva.

[61] Komunte, M. and Baguma, R. (2016) Information Needs of Startup Women Entrepreneurs in Uganda. Paper Presented at the Proceedings of the 5th International Conference on M4D Mobile Communication Technology for Development, Maputo, 21-22 October 2016.

[62] Allen, D.R. (2000) Learning the Facts of Life: Past and Present Experiences in a Rural Tanzanian Community. Africa Today, 47, 3-27.

https://doi.org/10.1353/at.2000.0059

[63] Asiimwe, J. (2001) Making Women's Land Rights a Reality in Uganda: Advocacy 
for Co-Ownership by Spouses. Yale Hum. Rts. \& Dev. LJ, 4, 171.

[64] Goode, P.M. (1989) Edible Plants of Uganda: The Value of Wild and Cultivated Plants as Food. Food \& Agriculture Organization, Rome.

[65] Ntozi, J.P. and Kabera, J.B. (1991) Family Planning in Rural Uganda: Knowledge and Use of Modern and Traditional Methods in Ankole. Studies in Family Planning, 22, 116-123. https://doi.org/10.2307/1966781

[66] Turinawe, E.B., Rwemisisi, J.T., Musinguzi, L.K., de Groot, M., Muhangi, D., de Vries, D.H., et al. (2016) Traditional Birth Attendants (TBAs) as Potential Agents in Promoting Male Involvement in Maternity Preparedness: Insights from a Rural Community in Uganda. Reproductive Health, 13, Article No. 24.

https://doi.org/10.1186/s12978-016-0147-7

[67] Lawson, T. (2003) Reorienting Economics. Vol. 20, Psychology Press, Hove.

[68] Mutema, E. (2019) Effectiveness of the Internal Control System in Public Sector Organisations in Uganda: A Case Study of National Agricultural Advisory Services (NAADS). Makerere University, Kampala.

[69] Nkundabanyanga, S.K., Nakyeyune, G.K. and Muhwezi, M. (2019) Management Mechanisms, Deterrence Measures and Public Finance Regulatory Compliance in Uganda. Journal of Public Budgeting, Accounting \& Financial Management, 31, 178196. https://doi.org/10.1108/JPBAFM-02-2018-0008

[70] Monteith, W. and Camfield, L. (2019) Business as Family, Family as Business: Female Entrepreneurship in Kampala, Uganda. Geoforum, 101, 111-121.

https://doi.org/10.1016/j.geoforum.2019.03.003

[71] Oriangi, G., Albrecht, F., Di Baldassarre, G., Bamutaze, Y., Mukwaya, P.I., Ardö, J. and Pilesjö, P. (2019) Household Resilience to Climate Change Hazards in Uganda. International Journal of Climate Change Strategies and Management, 12, 59-73. https://doi.org/10.1108/IJCCSM-10-2018-0069

[72] Epule, T.E. and New, M.G. (2019) Vulnerability of Crop Yields to Variations in Growing Season Precipitation in Uganda. SN Applied Sciences, 1, Article No. 899. https://doi.org/10.1007/s42452-019-0912-7

[73] Brown, M. (1996) Barriers to Women Managers' Advancement in Education in Uganda. International Journal of Educational Management, 10, 18-23. https://doi.org/10.1108/09513549610151668

[74] Tuwor, T. and Sossou, M.A. (2008) Gender Discrimination and Education in West Africa: Strategies for Maintaining Girls in School. International Journal of Inclusive Education, 12, 363-379. https://doi.org/10.1080/13603110601183115

[75] Unterhalter, E. (2012) Gender, Schooling and Global Social Justice. Routledge, London. https://doi.org/10.4324/9780203965849

[76] Mutibwa, P.M. (1992) Uganda since Independence: A Story of Unfulfilled Hopes. Africa World Press, Trenton.

[77] Pankhurst, D. (2002) Women and Politics in Africa: The Case of Uganda. Parliamentary Affairs, 55, 119-128. https://doi.org/10.1093/parlij/55.1.119

[78] Karimli, L., Samman, E., Rost, L. and Kidder, T. (2016) Factors and Norms Influencing Unpaid Care Work: Household Survey Evidence from Five Rural Communities in Colombia, Ethiopia, the Philippines, Uganda and Zimbabwe. Oxfam.

[79] Godfrey, A.B. (2010) Household Gender and Resource Relations: Women in the Marketing Arena of Income Generating Crops in Uganda. Eastern Africa Social Science Research Review, 26, 1-30. https://doi.org/10.1353/eas.0.0023

[80] Wright, K. (2017) Sexual Objectification of Female Bodies in Beauty Pageants, Por- 
nography, and Media. Dissenting Voices, 6, 125-146.

[81] Tamale, S. (2018) When Hens Begin to Crow: Gender and Parliamentary Politics in Uganda. Routledge, New York. https://doi.org/10.4324/9780429503085

[82] Sentumbwe, N. (1995) Sighted Lovers and Blind Husbands: Experiences of Blind Women in Uganda. In: Ingstad, B. and Whyte, S.R., Eds., Disability and Culture, University of California Press, Berkeley, 159-173. https://doi.org/10.1525/9780520342194-011

[83] Kagugube, J.L. (2017) Assessment of the Framework for Sustained Production of Gender Statistics in Uganda. United Nations Entity for Gender Equality and the Empowerment of Women, New York.

[84] Cooper, E. (2011) Challenges and Opportunities in Inheritance Rights in Uganda. Chronic Poverty Research Centre. https://doi.org/10.2139/ssrn.1775798

[85] Rutakumwa, R., Bukenya, D., Tumwekwase, G., Ssembajja, F. and Seeley, J. (2017) Gender, Land and Responses to Health and Environmental Shocks in Rural South Western Uganda. Journal of Gender, Agriculture and Food Security (Agri-Gender), 2, 33-51. https://doi.org/10.19268/JGAFS.222017.3

[86] Amone, C. (2018) Contested Citizenship, Religious Discrimination and the Growth of Nubian Identity in Northern Uganda. Globe: A Journal of Language, Culture and Communication, 6, 66-79.

[87] Schulz, D.E. (2018) Carving Out a Space for Equal Political Citizenship? Muslim Politics of Remembrance in Uganda Ways of Knowing Muslim Cultures and Societies. Brill, Leiden, 376-393. https://doi.org/10.1163/9789004386891 019

[88] Lubaale, G. (2019) Poverty in Uganda: Causes and Strategies for Reduction with Great Emphasis on Ethics and Ecological Justice. Sociology and Anthropology, 7, 9-19. https://doi.org/10.13189/sa.2019.070102 